\title{
Design and Thermal Analysis for Irradiation of Pyrolytic Carbon / Silicon Carbide Diffusion Couples in the High Flux Isotope Reactor
}

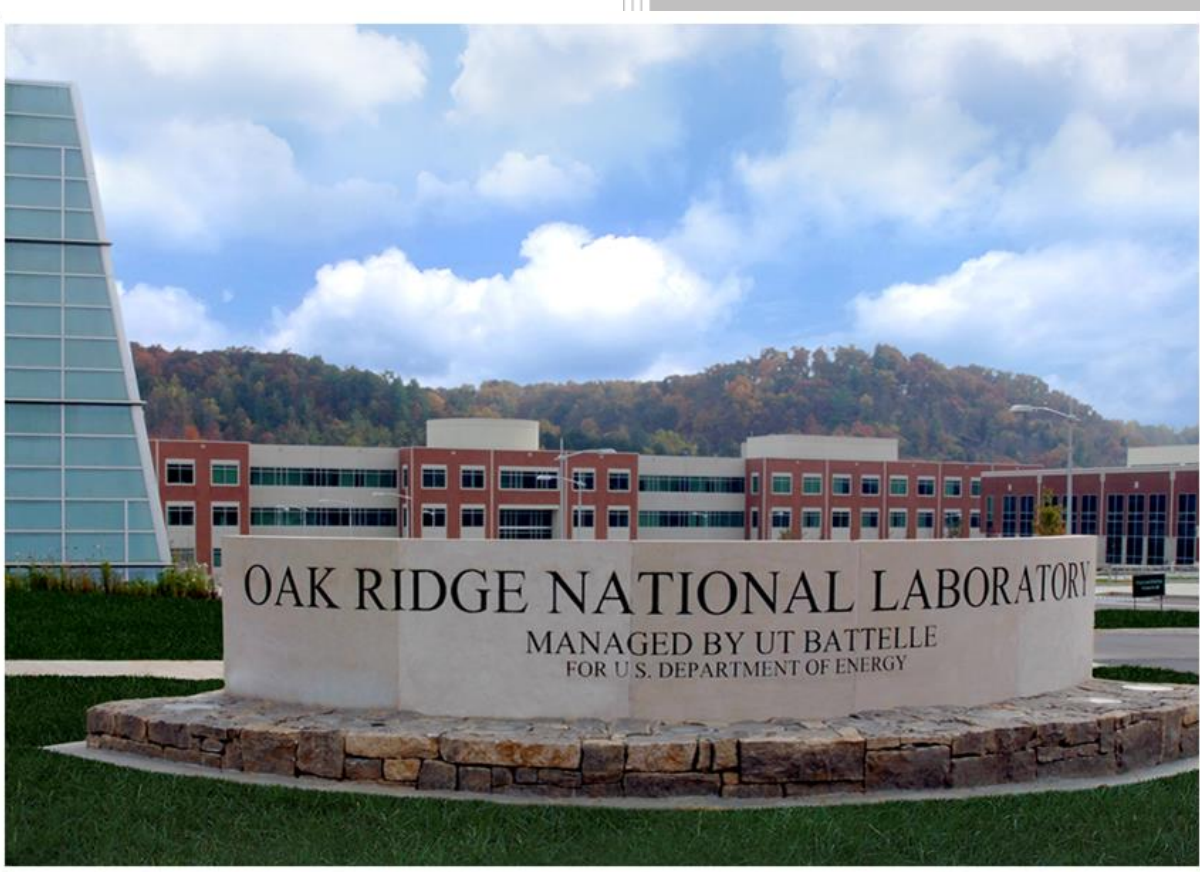

Approved for public release. Distribution is unlimited.

Christian M. Petrie Kurt Smith

Tyler Gerczak

August 14, 2017 


\title{
DOCUMENT AVAILABILITY
}

Reports produced after January 1, 1996, are generally available free via US Department of Energy (DOE) SciTech Connect.

Website http://www.osti.gov/scitech/

Reports produced before January 1, 1996, may be purchased by members of the public from the following source:

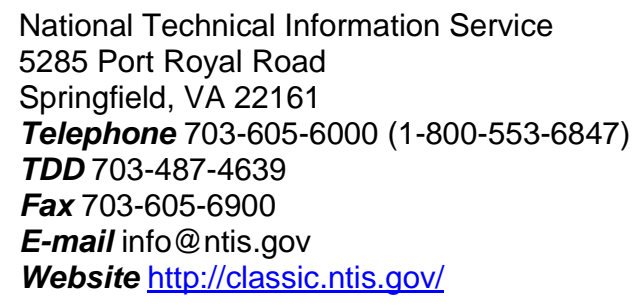

Reports are available to DOE employees, DOE contractors, Energy Technology Data Exchange representatives, and International Nuclear Information System representatives from the following source:

Office of Scientific and Technical Information

PO Box 62

Oak Ridge, TN 37831

Telephone 865-576-8401

Fax 865-576-5728

E-mail reports@osti.gov

Website http://www.osti.gov/contact.html

\begin{abstract}
This report was prepared as an account of work sponsored by an agency of the United States Government. Neither the United States Government nor any agency thereof, nor any of their employees, makes any warranty, express or implied, or assumes any legal liability or responsibility for the accuracy, completeness, or usefulness of any information, apparatus, product, or process disclosed, or represents that its use would not infringe privately owned rights. Reference herein to any specific commercial product, process, or service by trade name, trademark, manufacturer, or otherwise, does not necessarily constitute or imply its endorsement, recommendation, or favoring by the United States Government or any agency thereof. The views and opinions of authors expressed herein do not necessarily state or reflect those of the United States Government or any agency thereof.
\end{abstract}


Reactor and Nuclear Systems Division

Design and Thermal Analysis for Irradiation of Pyrolytic Carbon / Silicon Carbide Diffusion Couples in the High Flux Isotope Reactor

Christian M. Petrie

Kurt Smith

Tyler Gerczak

Date Published: August 14, 2017

NSUF Work Package \#: UF-17OR020709

Work Package Manager: Kory Linton

Milestone \#: M3UF-17OR0207092

Prepared by

OAK RIDGE NATIONAL LABORATORY

Oak Ridge, TN 37831-6283

managed by

UT-BATTELLE, LLC

for the

US DEPARTMENT OF ENERGY

under contract DE-AC05-00OR22725 



\section{CONTENTS}

CONTENTS

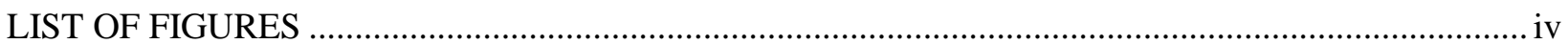

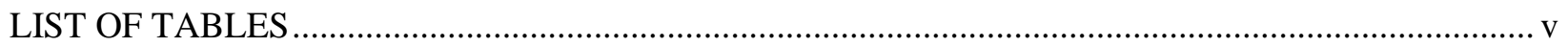

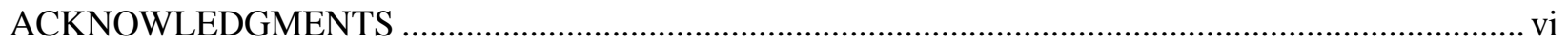

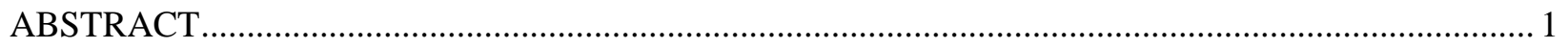

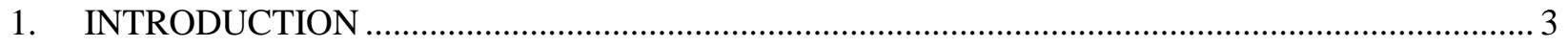

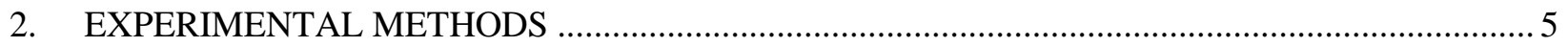

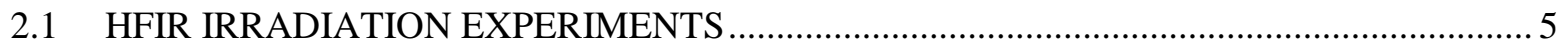

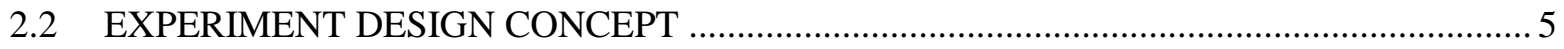

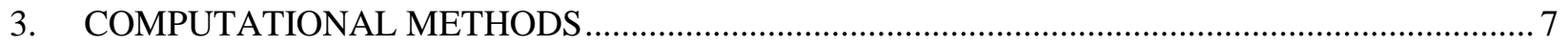

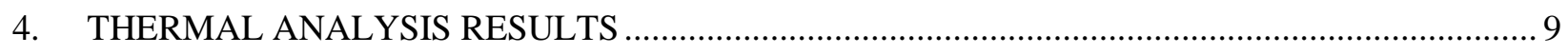

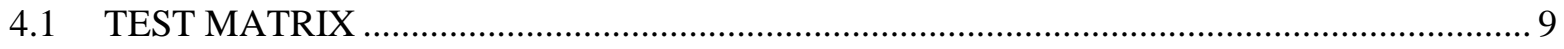

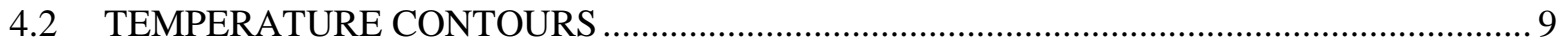

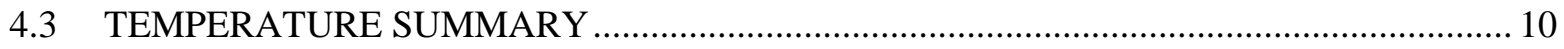

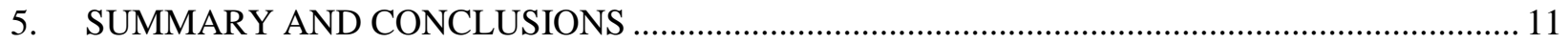

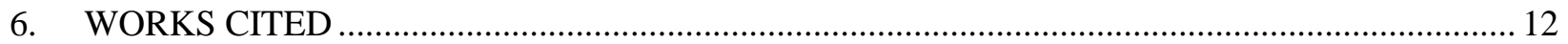

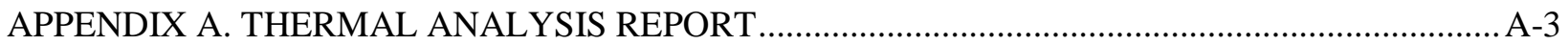




\section{LIST OF FIGURES}

Fig. 1. Schematic of $\mathrm{PyC} / \mathrm{SiC}$ diffusion couple with inset showing interfacial stitching. ......................... 4

Fig. 2. Section view showing irradiation capsule design concept......................................................... 6

Fig. 3. Predicted temperature contours showing (a) a section view of the internal components, (b) the specimens, and (c) the $\mathrm{SiC}$ temperature monitors............................................................... 10 


\section{LIST OF TABLES}

Table 1. Experiment materials and material property references..................................................... 7

Table 2. Thermal boundary conditions for hydraulic tube irradiation experiments.................................. 8

Table 3. Potential specimen types that could be included in the irradiation test matrix ............................ 9

Table 4. Summary of component temperatures, irradiation position, fill gas, and cold holder-tohousing gas gap. 


\section{ACKNOWLEDGMENTS}

This research was sponsored by the Nuclear Science User Facilities (NSUF) Program of the US Department of Energy (DOE), Office of Nuclear Energy. Neutron irradiation in the High Flux Isotope Reactor (HFIR) is made possible by the Office of Basic Energy Sciences, US DOE. The report was authored by UT-Battelle under Contract No. DE-AC05-00OR22725 with the US Department of Energy. The contributions of Kurt Terrani, ORNL program manager for the NSUF program, and Kory Linton, the project manager for this work, are gratefully acknowledged. 


\begin{abstract}
Tristructural-isotropic (TRISO)-coated particle fuel is a promising advanced fuel concept being considered for several advanced reactor applications and for accident-tolerant fuel for light water reactors. Accurate models and codes for TRISO fuel performance must be developed to ensure safe, efficient operation using this fuel form. One of the unresolved safety and maintenance concerns for TRISO fuel is the release of specific fission products $(\mathrm{Ag}, \mathrm{Eu}$, and $\mathrm{Sr}$ ). The silicon carbide ( $\mathrm{SiC}$ ) layer of TRISO fuel serves as the primary barrier to metallic fission products and actinides not retained in the fuel kernel. Recent experimental evidence suggests that diffusion of these fission products may be accelerated by irradiation. The objective of this effort is to improve the understanding of $\mathrm{Ag}, \mathrm{Ag}-\mathrm{Pd}, \mathrm{Eu}$, and $\mathrm{Sr}$ diffusion in the $\mathrm{SiC}$ layers of TRISO fuel particles by performing reactor irradiations and out-of-pile thermal experiments to separate the effects of irradiation and temperature. Small diffusion couple specimens with slab geometry and representative pyrolytic carbon $(\mathrm{PyC})$ and $\mathrm{SiC}$ layers will be fabricated using processes and equipment similar to those used to make TRISO particles. The PyC layer of these particles will be implanted with the desired fission products using ion accelerators, thus allowing for characterization of the diffusion profiles before and after heating and/or irradiation. This report summarizes the design and thermal analysis for the irradiation experiments, which will be performed in the flux trap of the High Flux Isotope Reactor (HFIR). Up to 40 specimens can be loaded into each rabbit capsule and irradiated in a hydraulic tube facility in the HFIR. Thermal analyses show that a specimen design temperature of $1,100^{\circ} \mathrm{C} \pm 50^{\circ} \mathrm{C}$ can be achieved by placing the specimens inside a holder fabricated from a $\mathrm{Nb}$ alloy and backfilling the rabbit capsule with a custom $\mathrm{He} / \mathrm{Ar}$ gas mixture.
\end{abstract}




\section{INTRODUCTION}

Tristructural-isotropic (TRISO)-coated particle fuel is a promising advanced fuel concept consisting of a spherical fuel kernel made of uranium oxide and uranium carbide, surrounded by a porous carbonaceous buffer layer and successive layers of dense inner pyrolytic carbon (IPyC), silicon carbide (SiC) deposited by chemical vapor, and dense outer pyrolytic carbon (OPyC). This fuel concept is being considered for advanced reactor applications such as high temperature gas-cooled reactors (HTGRs) and molten salt reactors (MSRs), as well as for accident-tolerant fuel for light water reactors (LWRs). Development and implementation of TRISO fuel for these reactor concepts support the US Department of Energy (DOE) Office of Nuclear Energy mission to promote safe, reliable nuclear energy that is sustainable and environmentally friendly. During operation, the $\mathrm{SiC}$ layer serves as the primary barrier to metallic fission products and actinides not retained in the kernel. It has been observed that certain fission products are released from TRISO fuel during operation, notably, $\mathrm{Ag}, \mathrm{Eu}$, and $\mathrm{Sr}$ [1]. Release of these radioisotopes causes safety and maintenance concerns.

Accurate models and codes for TRISO fuel performance must be developed to ensure safe, efficient operation using this fuel form. These models require a thorough understanding of fission product diffusion kinetics in the various coating layers. Most diffusion kinetics parameters that are currently available originate from fractional release measurements from irradiated TRISO fuel particles. These measurements (particularly those for $\mathrm{Ag}$ ) have large uncertainties due to the indirect nature of the analysis, the varying pedigrees of the fuel particles, the uncertainty of fission product production, a limited understanding of boundary conditions, and the complex, time-dependent nature of fuel irradiations. Recent efforts have focused on providing diffusion kinetics of fission product elements in $\mathrm{SiC}$ through simplified surrogate diffusion systems. The transport of $\mathrm{Ag}$ in $\mathrm{SiC}$ has received the most attention due to the magnitude of the release and the complex release behavior from TRISO fuel. Most experiments have focused on surrogate diffusion couple designs, which differ from TRISO fuel systems due to $\mathrm{SiC}$ variations, diffusion species source effects (direct ion implantation, high activity sources), and the lack of neutron irradiation. Results from surrogate diffusion couple experiments show no consistency in diffusion kinetics or possible mechanisms [2].

Recent ion implantation diffusion studies showed the potential influence of radiation damage on $\mathrm{Ag}$ transport in $\mathrm{SiC}$ [3]. The influence of irradiation on fission product transport is also noted from post-irradiation examination (PIE) safety testing of AGR-1 TRISO fuel. After irradiation, high fractional $\mathrm{Ag}$ release from irradiated particles with intact TRISO coatings was observed [1]. Post-irradiation heating of the compacts up to $1700^{\circ} \mathrm{C}$ did not result in significant additional $\mathrm{Ag}$ release [4]. On the other hand, Eu and $\mathrm{Sr}$ fission product release through intact TRISO particles at temperatures below $1800^{\circ} \mathrm{C}$ could not be conclusively confirmed due to retention of these fission product species in the compact matrix. Similar observations were made after comparing in-pile release with release during post-irradiation heating of HRB-15B fuel [5]. These observations suggest the likely influence of neutron radiation on fission product diffusion in the TRISO SiC layer, and they provide motivation to study the effect of neutron radiation-enhanced diffusion to obtain representative diffusion kinetic parameters.

The optimal approach to obtaining accurate diffusion kinetic data on fission product release is to analyze irradiated TRISO fuel particles. However, the large variation in irradiation conditions across fuel compacts and the complex, time-dependent diffusion sources and thermal histories do not allow for accurate diffusion analysis. Additionally, the spherical geometry of the TRISO fuel particle does not lend itself to the sensitive techniques required to measure the precise depth profiles needed to determine diffusion behavior. Separate effects testing of representative fission product diffusion from the IPyC layer through the $\mathrm{SiC}$ layer could provide accurate measurements of diffusion kinetics without the complications of integral TRISO particle testing. For these separate effects tests to be relevant to TRISO 
fuel performance models, the tests must include representative TRISO fuel construction and fission products, and they must account for the influence of neutron irradiation. At this writing, no surrogate system has been able to provide such a system to study diffusion of select species in $\mathrm{SiC}$.

Oak Ridge National Laboratory (ORNL) is leveraging coating systems developed to fabricate fuel for the AGR-1 irradiation campaign to produce diffusion couple systems with the unique $\mathrm{PyC} / \mathrm{SiC}$ interface and a $\mathrm{SiC}$ microstructure identical to the $\mathrm{SiC}$ found in TRISO fuel. The diffusion couple coupon specimens will have slab geometry to simplify the fabrication process and the post-irradiation depth profiling. Fig. 1 shows a schematic of the diffusion couple specimen.

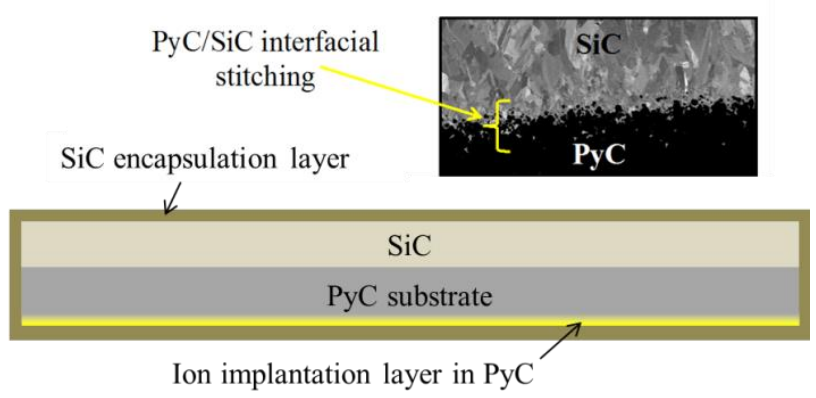

Fig. 1. Schematic of PyC/SiC diffusion couple with inset showing interfacial stitching.

The diffusing fission product species will be introduced into the PyC layer, which mitigates any issues resulting from implantation effects in the $\mathrm{SiC}$ [6]. The implantation energy and dose will be tailored to reflect the concentrations present in TRISO fuel particles at the end of life. This approach also allows for multiple species to be introduced so that the potential of Pd-assisted Ag diffusion can be further understood. The diffusion couples will reflect the encapsulated nature of TRISO fuel, allowing for insertion into the High Flux Isotope Reactor (HFIR) so that neutron radiation-enhanced diffusion can be studied. The influence of neutron radiation-enhanced diffusion will be investigated through a comparative study of neutron-irradiated diffusion couples and thermally exposed diffusion couples. This report summarizes the HFIR irradiation experiment to be used to assess neutron radiation-enhanced diffusion, including the irradiation capsule design concept and thermal analyses. 


\section{EXPERIMENTAL METHODS}

\subsection{HFIR IRRADIATION EXPERIMENTS}

The irradiation experiments described in this document will be performed in the hydraulic tube facility inside the flux trap of ORNL's HFIR. The HFIR is a beryllium-reflected, pressurized, light water-cooled and moderated flux trap-type reactor [7]. The core consists of aluminum-clad involute-fuel plates which currently use highly enriched ${ }^{235} \mathrm{U}$ fuel at a power level of $85 \mathrm{MW}$. A typical HFIR cycle is 25 days. The reactor core consists of two concentric annular regions, each approximately $61 \mathrm{~cm}$ in height. The flux trap region is located inside the fuel region. The HFIR fuel and all experiment vessels are cooled by the reactor's primary coolant, which is approximately $50-60^{\circ} \mathrm{C}$. Most experiments are conducted in the flux trap in small, un-instrumented rabbit capsules. The hydraulic tube (HT) allows for short-term (less than a full cycle) irradiations to be performed. As many as 9 rabbits can be stacked vertically and irradiated simultaneously inside the hydraulic tube. Positions are numbered from the bottom to the top of the hydraulic tube. Position HT-5 aligns with the axial midplane of the reactor. The irradiations described in this document are designed for the HT- 6 position, which is located just above the axial midplane, or the HT-4 position, which is located just below the axial midplane.

The goal of this work is to design an experiment to contain the PyC/SiC diffusion couple specimens inside a HFIR-approved irradiation vehicle so that they can accumulate the desired dose while being irradiated at the design temperature. Neutron and gamma radiation from the HFIR fuel cause heating of the experiment materials. This heating is accurately determined using neutronics models of the HFIR core. These data are used as inputs to thermal analyses to predict component temperatures during irradiation. As mentioned previously, experiments in the flux trap are almost always un-instrumented. Passive SiC temperature monitors (TMs) can be used to determine the irradiation temperature postirradiation [8]. However, detailed neutronic and thermal analyses are required to ensure that design temperatures are achieved. Experiment designs typically use a small insulating gas gap. The size of the gap and the choice of the fill gas (typically helium, neon, or argon) inside the experiment are established so that the heat generated in the experimental components passes through the gas gap and results in the desired temperature drop across the gap. The temperature drop is a function of the heat flux through the gap, the thermal conductivity of the fill gas, and the size of the gas gap.

\subsection{EXPERIMENT DESIGN CONCEPT}

The overall design of the irradiation experiments developed in this work is shown in the section views of Fig. 2. The outer containment for the irradiation experiment is the rabbit capsule housing, which is directly cooled on the outer surface by the HFIR's primary coolant. As many as 40 diffusion couple specimens $(3 \mathrm{~mm} \times 4 \mathrm{~mm} \times 0.25 \mathrm{~mm})$ are placed inside small cutouts in a graphite container. The container is then placed inside a square cutout in a cylindrical holder made from a $\mathrm{Nb}-1 \mathrm{Zr}$ alloy. Passive

$\mathrm{SiC} \mathrm{TMs}$ line the inside of the holder cutout, and $\mathrm{SiC}$ retainer springs keep the graphite container pressed into one corner of the cutout. Temperature is controlled by varying the concentration of a helium/argon gas mixture and the size of the gas gap between the holder and the housing. Varying the gas mixture changes the effective thermal conductivity of the gas gap. Centering thimbles are inserted inside counterbores in the ends of the holder to keep the holder centered inside the housing and to maintain a constant gas gap between the holder and the housing. Wires are inserted through the thimbles and the radial holes in the holder to ensure that the thimbles cannot dislodge from the holder. The small raised features above and below the base of the centering thimble (see Fig. 2) reduce the contact area between the centering thimble and the contacting components (the holder and the bottom of the housing). These features significantly reduce axial heat losses through the thimbles. Grafoil insulator disks are also stacked on both ends of the capsule to further reduce axial heat losses. Quartz wool (not shown) is packed into the ends of the cutouts in the graphite container to keep the specimens from falling out. 


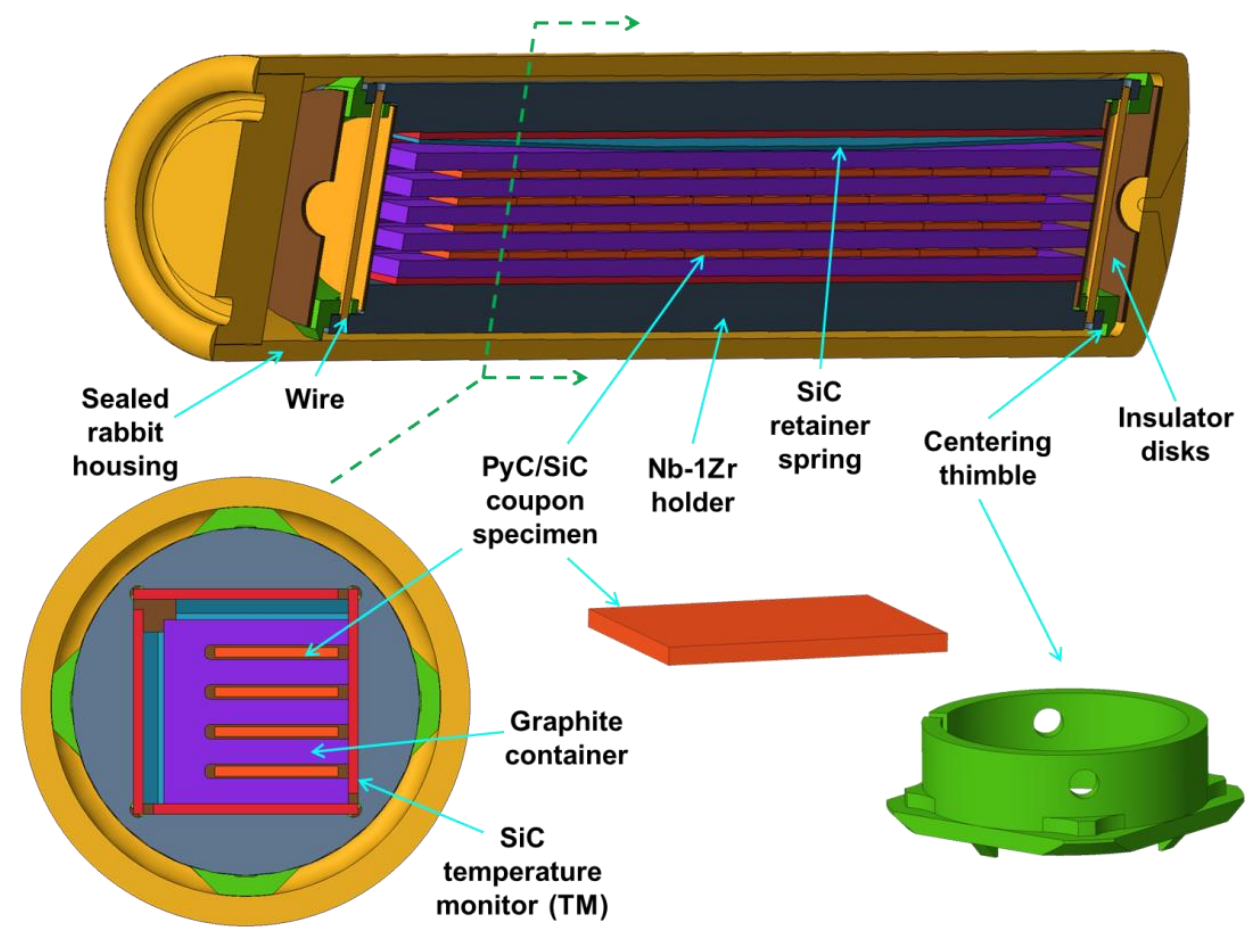

Fig. 2. Section view showing irradiation capsule design concept. 


\section{COMPUTATIONAL METHODS}

Three-dimensional (3D) thermal analyses are performed using the ANSYS finite element software package to predict temperature distributions inside the experiment. These analyses use material-dependent heat generation rates (heat per unit mass) calculated from neutronics analyses. Custom user-defined macros have been incorporated into ANSYS to determine thermal contact conductance between components either in contact or separated by small gas gaps that expand or contract due to thermal expansion [9]. In this way, gas gaps are not directly meshed, which significantly reduces computational time. Computer aided design (CAD) models are imported into ANSYS and meshed using 20-node hexagonal elements with a mesh size ranging from $0.2-0.7 \mathrm{~mm}$. Thermal contacts are defined to allow heat to be transferred between multiple bodies. Gas gap heat transfer is assumed to only result from conduction and radiation, as there is very little space available for natural convection to occur. Gaps are typically on the order of microns to a few millimeters, and the total internal length of the capsule is less than $60 \mathrm{~mm}$. The solver accounts for thermal expansion using temperature-dependent thermal expansion data and the temperatures of contact and target surface nodes.

The ORNL Thermal Hydraulic and Irradiation Engineering Group maintains a database of design and analysis calculations (DACs) that include temperature-dependent thermophysical material properties used in thermal analyses. Some properties for $\mathrm{SiC}$ and $\mathrm{PyC}$ also include radiation dose-dependence. Properties are primarily obtained from CINDAS [10], MatWeb [11], and various literature sources. Properties of gas mixtures are calculated using the methods described by Wahid et al. [12]. Material properties for this calculation are included in the DACs, as shown in Table 1 and are available upon request. Specimens are modeled as $100 \%$ PyC. However, because of their small size, the specimens do not have much effect on the total heat load inside the capsule, and temperature gradients within the specimens are very small.

Table 1. Experiment materials and material property references

\begin{tabular}{lll}
\hline \multicolumn{1}{c}{ Part } & \multicolumn{1}{c}{ Material } & \multicolumn{1}{c}{ Reference } \\
\hline Housing, end cap & Aluminum & DAC-10-03-PROP_AL6061 [13] \\
Specimen & PyC/SiC & DAC-16-07-PROP_PYROLYTIC_CARBON [14] \\
Container & Graphite & DAC-10-15-PROP_POCO-GRAPHITE [15] \\
Holder & Nb-1Zr & DAC-10-12-PROP_NB1ZR [16] \\
Centering thimbles & Titanium & DAC-11-14-PROP_TI6AL4V [17] \\
Insulators & Grafoil & DAC-11-16-PROP_GRAFOIL [18] \\
$\begin{array}{l}\text { Temperature monitors and } \\
\quad \text { retainer springs }\end{array}$ & SiC & DAC-10-06-PROP_SIC(IRR) [19] \\
Wires and support disks & Molybdenum & DAC-10-11-PROP_MOLY [20] \\
Fill gas & Argon & DAC-10-09-PROP_ARGON [21] \\
Fill gas & Helium & DAC-10-02-PROP_HELIUM [22] \\
\hline
\end{tabular}

Convection boundary conditions are applied to the outer surface of the housing. Details of the calculation of the convective heat transfer coefficients and bulk coolant temperatures are summarized in DAC-11-01RAB03 [23]. These parameters were calculated using turbulent flow correlations and the axial power profile (resulting from neutron and gamma heat generation in the coolant) specific to the hydraulic tube facility in the HFIR flux trap. Temperatures calculated in the thermal analyses are not extremely sensitive to the convection heat transfer coefficient, as the housing surface temperatures are typically only $\sim 10^{\circ} \mathrm{C}$ warmer than the bulk coolant temperature. 
The heat generation rates vary as a function of axial position from the midplane of the reactor core. Peak heat generation rates (at the core midplane), parameters for determining the axial profile, and convection parameters are summarized in Table 2 . All heat generation rates were determined in DAC-10-18-RAB02 [24] except for the titanium heat generation rate, which was determined in HFIR safety basis calculation C-HFIR-2013-003 [25]. These heat generation rates include contributions from prompt neutrons, fission photons and secondary photons produced by the fission neutrons, fission product decay photons, and decay (primarily due to beta emission) of activation sources. Nuclear heating in HFIR is dominated by photon absorption in the materials used in this experiment.

\section{Table 2. Thermal boundary conditions for hydraulic tube irradiation experiments}

\begin{tabular}{lc}
\hline Parameter & Value \\
\hline Heat transfer coefficient & $31.6 \mathrm{~kW} \mathrm{~m}^{-2} \mathrm{~K}^{-1}$ \\
Bulk coolant temperature & $53^{\circ} \mathrm{C}$ \\
Peak heat generation rate for aluminum & $31.5 \mathrm{~W} / \mathrm{g}$ \\
Peak heat generation rate for PyC, graphite, & $32.3 \mathrm{~W} / \mathrm{g}$ \\
and grafoil & \\
Peak heat generation rate for Nb-1Zr & $44.0 \mathrm{~W} / \mathrm{g}$ \\
Peak heat generation rate for titanium & $34.7 \mathrm{~W} / \mathrm{g}$ \\
Peak heat generation rate for $\mathrm{SiC}$ & $31.9 \mathrm{~W} / \mathrm{g}$ \\
Peak heat generation rate for molybdenum & $42.3 \mathrm{~W} / \mathrm{g}$ \\
Correlating parameter $(\sigma)$ & $30.07 \mathrm{~cm}$ \\
\hline
\end{tabular}

The local heat generation rate is estimated using the following profile:

$$
\mathrm{q}(\text { material, } \mathrm{z})=\mathrm{q}_{\text {peak }}(\text { material }) \cdot \exp \left[-\left(\frac{\mathrm{z}}{\sigma}\right)^{2}\right] \text {, }
$$

where:

$\mathrm{q}=$ local heat generation rate as a function of the material and axial location,

$\mathrm{q}_{\text {peak }}=$ heat generation rate at the HFIR midplane as a function of material,

$\mathrm{z}=$ axial location in the HFIR, where the midplane is at $\mathrm{z}=0$, and

$\sigma=$ correlating parameter 


\section{THERMAL ANALYSIS RESULTS}

\subsection{TEST MATRIX}

Table 3 summarizes all possible specimen combinations that could be included in the irradiation test matrix. All specimen types to be included in the irradiation testing will also be included in hightemperature furnace testing in the absence of irradiation. This will separate the effects of thermal and irradiation-assisted diffusion. The baseline specimen condition will be produced with AGR-2 layer properties. Other specimen variants will include a tailored $\mathrm{SiC}$ microstructure with larger grains (SiC variant), a controlled PyC/SiC interface with minimal stitching compared to the AGR-2 baseline (PyC variant), and a specimen (RH-SiC) that uses commercially available chemical vapor deposition (CVD) $\mathrm{SiC}$ from Dow Chemical Company (formerly Rohm and Haas). All irradiations will be performed with a nominal design temperature of $1,100^{\circ} \mathrm{C}$ with dose ranging from $0.5-1.0 \mathrm{dpa}$. Because there are two irradiation dose levels and one design temperature, a total of two rabbits will be irradiated. Each rabbit can contain up to 40 specimens. Therefore, with 10 different types of specimens (condition + implanted species), as many as 4 specimens of each type can be accommodated in each rabbit.

Table 3. Potential specimen types that could be included in the irradiation test matrix

\begin{tabular}{|c|c|c|c|}
\hline $\begin{array}{l}\text { Specimen } \\
\text { condition }\end{array}$ & $\begin{array}{c}\text { Implanted } \\
\text { species }\end{array}$ & $\begin{array}{c}\text { Irradiation } \\
\text { dose }\end{array}$ & $\begin{array}{c}\text { Irradiation } \\
\text { temperature }\end{array}$ \\
\hline & $\mathrm{Ag}$ & \multirow{9}{*}{$\begin{array}{c}0.5 \mathrm{dpa} \\
1.0 \mathrm{dpa}\end{array}$} & \multirow{9}{*}{$1,100 \pm 50^{\circ} \mathrm{C}$} \\
\hline & $\mathrm{Ag}+\mathrm{Pd}$ & & \\
\hline Baseline & $\mathrm{Eu}$ & & \\
\hline & $\mathrm{Sr}$ & & \\
\hline IPyC variant & $\begin{array}{c}\mathrm{Ag} \\
\mathrm{Ag}+\mathrm{Pd}\end{array}$ & & \\
\hline \multirow{3}{*}{$\mathrm{SiC}$ variant } & $\mathrm{Ag}$ & & \\
\hline & $\mathrm{Eu}$ & & \\
\hline & $\mathrm{Sr}$ & & \\
\hline RH-SiC & $\mathrm{Ag}$ & & \\
\hline
\end{tabular}

\subsection{TEMPERATURE CONTOURS}

Fig. 3 shows temperature contours predicted by the thermal analyses. The reductions in temperature at the ends of the specimen holder and the specimens themselves are due to axial heat losses through the tabs of the centering thimbles. However, the small raised features of the centering thimbles described in Section 2.2 keep the axial temperature reductions very low $\left(\sim 45^{\circ} \mathrm{C}\right.$ in the specimens). The specimen temperatures remain within the desired range of $1,100 \pm 50^{\circ} \mathrm{C}$. Furthermore, the temperatures of the passive $\mathrm{SiC} \mathrm{TMs}$ $\left(1,050-1,115^{\circ} \mathrm{C}\right)$ are close to the temperatures of the specimens $\left(1,089-1,135^{\circ} \mathrm{C}\right)$, which assures that the TMs will give a good indication of the actual specimen temperature. The difference in temperature between the four TMs is because the graphite specimen container is pressed against two of the four interior walls of the specimen holder. This forces more heat to pass through the two walls that are in contact compared to the other two walls that are not in direct contact. The greater amount of heat passing through these two walls (and through two of the four TMs) results in slightly higher temperatures for these two TMs. 


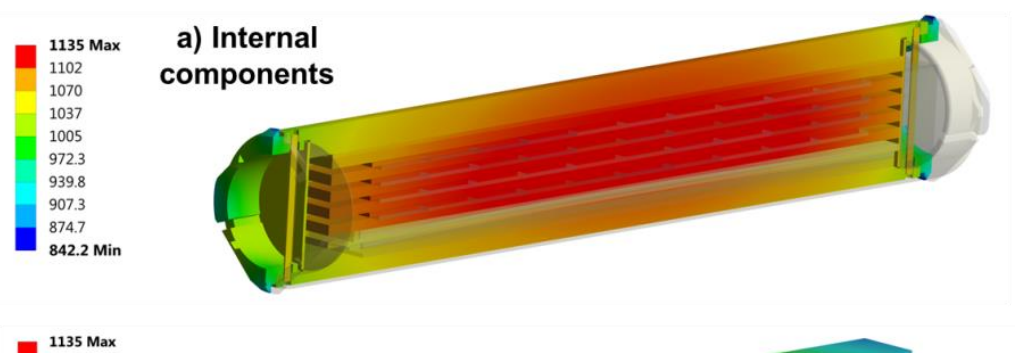

b) Specimens

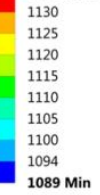

\section{b) Specimens}
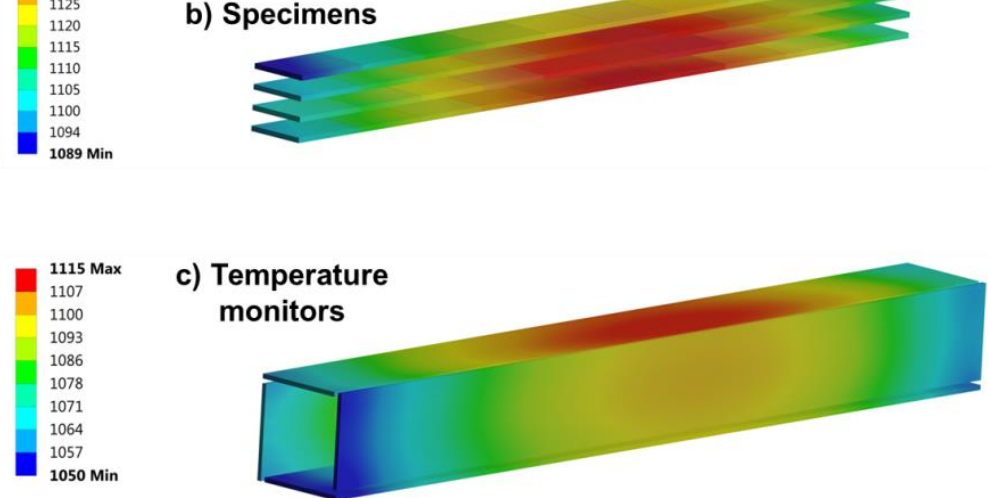

Fig. 3. Predicted temperature contours showing (a) a section view of the internal components, (b) the specimens, and (c) the $\mathrm{SiC}$ temperature monitors.

\subsection{TEMPERATURE SUMMARY}

Table 4 summarizes average, minimum, and maximum temperatures for all important components, in addition to other design parameters such as the irradiation position, fill gas, and outer diameter of the holder. More details are provided in the complete ANSYS reports provided in APPENDIX A. A fill gas with a $40.5 \% \mathrm{He}$, Ar balance was chosen. This is a standard gas composition that results in a thermal conductivity essentially equivalent to neon gas. Neon is not used often due to the higher cost. The holder's $9.01 \mathrm{~mm}$ outer diameter, combined with a nominal housing inner diameter of $9.52 \mathrm{~mm}$, results in a nominal cold (room temperature) holder-to-housing gas gap of $255 \mu \mathrm{m}$. Depending on the as-inspected value of the holder, a suitable housing will be selected so that the as-built holder-to-housing gas gap matches the desired $255 \mu \mathrm{m}$ gap as close as possible.

Table 4. Summary of component temperatures, irradiation position, fill gas, and cold holder-to-housing gas gap

\begin{tabular}{|c|c|c|c|c|c|c|}
\hline \multirow{2}{*}{ Position } & \multirow{2}{*}{ Fill gas } & \multirow{2}{*}{ Gas gap } & \multirow{2}{*}{ Part } & \multicolumn{3}{|c|}{ Temperature $\left({ }^{\circ} \mathbf{C}\right)$} \\
\hline & & & & Average & Minimum & Maximum \\
\hline \multirow{8}{*}{$\begin{array}{c}\text { HT-4 or } \\
\text { HT-6 }\end{array}$} & \multirow{8}{*}{$\begin{array}{l}40.5 \% \\
\text { He, Ar } \\
\text { balance }\end{array}$} & \multirow{8}{*}{$255 \mu \mathrm{m}$} & Specimens & 1,120 & 1,089 & 1,135 \\
\hline & & & TM1 & 1,096 & 1,059 & 1,113 \\
\hline & & & TM2 & 1,085 & 1,050 & 1,101 \\
\hline & & & TM3 & 1,084 & 1,050 & 1,101 \\
\hline & & & TM4 & 1,097 & 1,060 & 1,115 \\
\hline & & & Container & 1,113 & 1,064 & 1,133 \\
\hline & & & Holder & 1,077 & 1,009 & 1,106 \\
\hline & & & Housing & 66 & 57 & 73 \\
\hline
\end{tabular}




\section{SUMMARY AND CONCLUSIONS}

This report summarizes the capsule design and thermal analysis that was performed for irradiation testing of PyC/SiC diffusion couple specimens in the hydraulic tube facility of the HFIR. This design will allow for separation of the effects of radiation and temperature on the diffusion of select metallic fission products in the $\mathrm{SiC}$ layers of TRISO fuel particles. Ultimately, the data gathered from these experiments will assist in the development of accurate models and codes for TRISO fuel performance, which are needed to ensure safe and efficient operation of this fuel for advanced reactor applications or for use as an accident-tolerant fuel for LWRs. The rabbit capsule design allows for up to $40 \mathrm{PyC} / \mathrm{SiC}$ diffusion couple specimens to be loaded inside a rectangular graphite container, with small slots to accommodate the specimens. The graphite container is placed inside a $\mathrm{Nb}-1 \mathrm{Zr}$ specimen holder that is centered inside the rabbit housing using titanium centering thimbles. Temperature is controlled by varying the backfill gas (a $\mathrm{He} / \mathrm{Ar}$ gas mixture) and the size of the gas gap between the holder and the rabbit housing. Thermal analyses show that a design temperature of $1,100^{\circ} \mathrm{C}$ can be achieved in the specimens with temperature gradients of $\sim 45^{\circ} \mathrm{C}$. These analyses show that a $40.5 \% \mathrm{He}$ (Ar balance) gas mixture and a holder-tohousing gas gap of $255 \mu \mathrm{m}$ are required to achieve the desired temperatures. 


\section{WORKS CITED}

1. Demkowicz, P.A., et al., "Irradiation Performance of AGR-1 High Temperature Reactor Fuel," in Proceedings of the HTR 2014. 2014: Weihai, China. p. HTR2014-31182.

2. Malherbe, J.B., "Diffusion of fission products and radiation damage in SiC," Journal of Physics D: Applied Physics, 46 (2013) p. 473001.

3. Gerczak, T.J., et al., "Observations of Ag diffusion in ion implanted SiC," Journal of Nuclear Materials, 461 (2015) p. 314-324.

4. Morris, R.N., et al., "Performance of AGR-1 High-Temperature Reactor Fuel During PostIrradiation Heating Tests," in Proceedings of the HTR 2014. 2014: Weihai, China. p. HTR201431135.

5. Bullock, R.E., "Fission-product release during postirradiation annealing of several types of coated fuel particles," Journal of Nuclear Materials, 125 (1984) p. 304-319.

6. Dwaraknath, S. and G.S. Was, "Development of a multi-layer diffusion couple to study fission product transport in $\beta$-SiC," Journal of Nuclear Materials, 444 (2014) p. 170-174.

7. High Flux Isotope Reactor Technical Parameters, Oak Ridge National Laboratory. [cited 27 July, 2016]; Available from: http://neutrons.ornl.gov/hfir/parameters.

8. Campbell, A., et al., "Method for analyzing passive silicon carbide thermometry with a continuous dilatometer to determine irradiation temperature," Nuclear Instruments and Methods in Physics Research B, 370 (2016) p. 49-58.

9. McDuffee, J.L., "Heat Transfer Through Small Moveable Gas Gaps in a Multi-Body System Using the ANSYS Finite Element Software," in Proceedings of ASME 2013 Heat Transfer Summer Conference. 2013: Minneapolis, MN. p. 17783.

10. CINDAS, LLC: Global Benchmark for Critically Evaluated Materials Properties Data, [cited 27 July, 2016]; Available from: http://cindasdata.com.

11. MatWeb: Material Property Data, [cited 27 July, 2016]; Available from: http://matweb.com/.

12. Wahid, S.M.S. and C.V. Madhusudana, "Gap conductance in contact heat transfer," International Journal of Heat and Mass Transfer, 43 (2000) p. 4483-4487.

13. McDuffee, J.L., Thermophysical Properties for AL6061, DAC-10-03-PROP_AL6061, Rev.2, Oak Ridge National Laboratory, Thermal Hydraulics and Irradiation Engineering Group: Oak Ridge, TN (2013).

14. Petrie, C.M., Thermophysical Properties for Pyrolytic Carbon, DAC-16-07PROP_PYROLYTIC_CARBON, Rev. 0, Oak Ridge National Laboratory: Oak Ridge, TN (2017).

15. McDuffee, J.L., Thermophysical Properties for POCO Graphite, DAC-10-15-PROP_POCOGRAPHITE, Rev. 1, Oak Ridge National Laboratory: Oak Ridge, TN (2013).

16. McDuffee, J.L., Thermophysical Properties for Nb1Zr, DAC-10-12-PROP_NB1ZR, Rev. 1, Oak Ridge National Laboratory: Oak Ridge, TN (2013).

17. McDuffee, J.L., Thermophysical Properties for Titanium Alloy Ti-6Al4V, DAC-11-14PROP_TI6AL4V, Rev. 1, Oak Ridge National Laboratory: Oak Ridge, TN (2013).

18. McDuffee, J.L., Thermophysical Properties for Flexible Graphite, DAC-11-16PROP_GRAFOIL, Rev. 0, Oak Ridge National Laboratory: Oak Ridge, TN (2013).

19. McDuffee, J.L., Thermophysical Properties for Irradiated SiC, DAC-10-06-PROP_SIC(IRR), Rev. 2, Oak Ridge National Laboratory, Thermal Hydraulics and Irradiation Engineering Group: Oak Ridge, TN (2013).

20. McDuffee, J.L., Thermophysical Properties for Molybdenum, DAC-10-11-PROP_MOLY, Rev. 1, Oak Ridge National Laboratory: Oak Ridge, TN (2013).

21. McDuffee, J.L., Thermophysical Properties for Argon, DAC-10-09-PROP_ARGON, Rev. 0, Oak Ridge National Laboratory, Thermal Hydraulics and Irradiation Engineering Group: Oak Ridge, TN (2010). 
22. McDuffee, J.L., Thermophysical Properties for Helium, DAC-10-02-PROP_HELIUM, Rev. 0, Oak Ridge National Laboratory, Thermal Hydraulics and Irradiation Engineering Group: Oak Ridge, TN (2010).

23. McDuffee, J.L., Heat Transfer Coefficients and Bulk Temperatures for HFIR Rabbit Facilities, DAC-11-01-RAB03, Rev. 0, Oak Ridge National Laboratory, Thermal Hydraulics and Irradiation Engineering Group: Oak Ridge, TN (2011).

24. McDuffee, J.L., Heat Generation Rates for Various Rabbit Materials in the Flux Trap of HFIR, DAC-10-18-RAB02, Rev. 0, Oak Ridge National Laboratory, Thermal Hydraulics and Irradiation Engineering Group: Oak Ridge, TN (2011).

25. Daily, C., Heat Generation Rates for Various Titanium and Silicon Compounds in the Flux Trap of HFIR, C-HFIR-2013-003, Rev. 0, Oak Ridge National Laboratory: Oak Ridge, TN (2013). 


\section{APPENDIX A. THERMAL ANALYSIS REPORT}




$$
\text { A-2 }
$$




\section{APPENDIX A. THERMAL ANALYSIS REPORT}

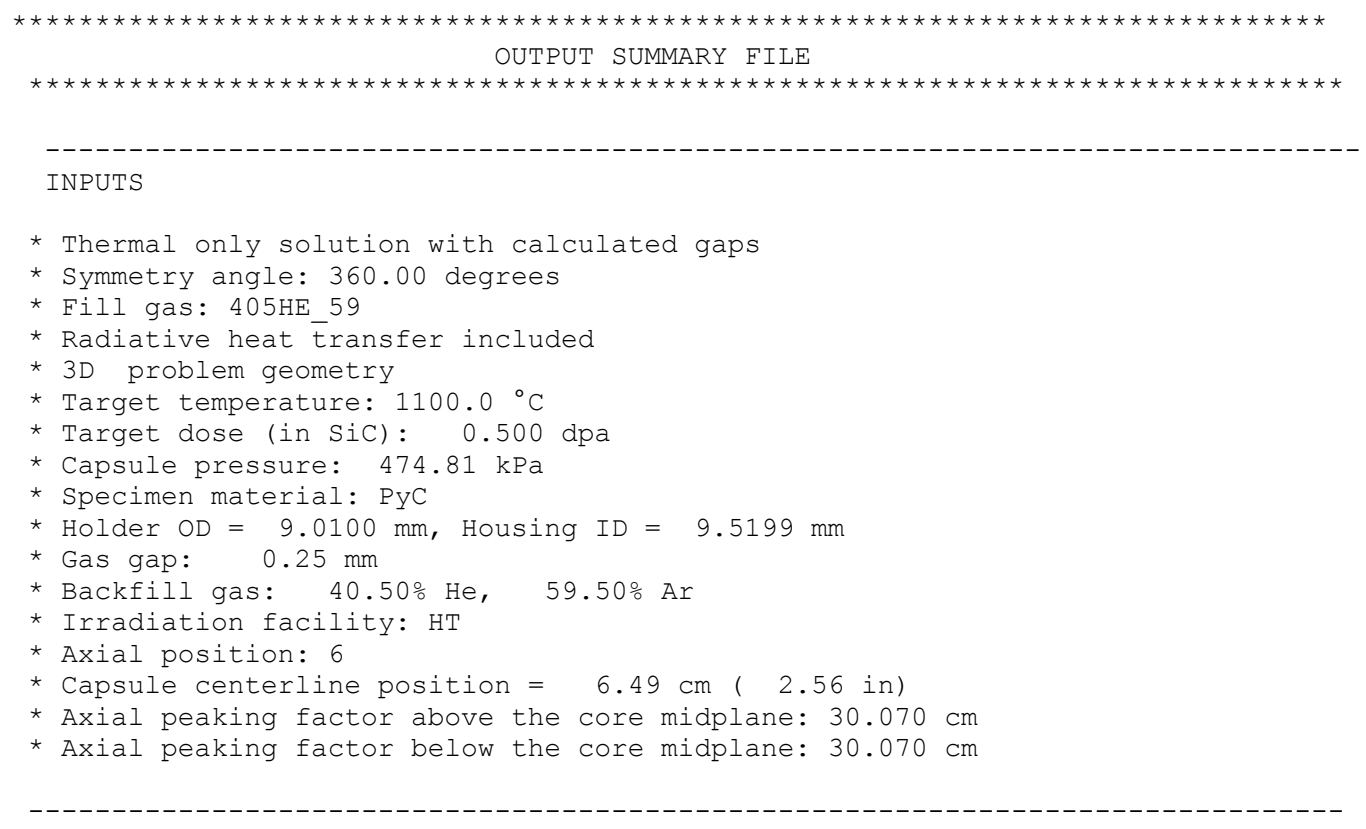

BOUNDARY CONDITIONS

Heat generation rate scaling factor $=1.0000$

Heat transfer coefficient $=31600 \cdot \mathrm{W} / \mathrm{m}^{2} \cdot{ }^{\circ} \mathrm{C}$

Bulk coolant temperature $=53.0^{\circ} \mathrm{C}$

HEAT GENERATION

\begin{tabular}{|c|c|c|c|c|c|}
\hline \multicolumn{2}{|c|}{ Part } & $\begin{array}{l}\text { Material } \\
-\end{array}$ & $\begin{array}{l}\text { Heat Gen. } \\
\text { @Midplane } \\
\text { (W/kg) }\end{array}$ & $\begin{array}{c}----- \text { Heat } \\
\text { @Midplane } \\
\text { (W) }\end{array}$ & $\begin{array}{c}\text { Load ---- } \\
\text { @Location } \\
\text { (W) }\end{array}$ \\
\hline 1) & Grafoil.1 & GRAFOIL & 32300 . & 0.2 & 0.2 \\
\hline 3) & Grafoil.2 & GRAFOIL & 32300 . & 0.2 & 0.2 \\
\hline 5) & Holder & $\mathrm{NB}-1 \mathrm{ZR}$ & 44000 & 637.3 & 609.1 \\
\hline 7) & Foil.1 & Moly & 42300 & 1.5 & 1.5 \\
\hline 9) & Foil.2 & Moly & 42300 & 1.5 & 1.4 \\
\hline 11) & Grafoil.3 & GRAFOIL & 32300 . & 0.2 & 0.2 \\
\hline 13) & Grafoil.4 & GRAFOIL & 32300 . & 0.2 & 0.2 \\
\hline 15) & TM.1 & $\operatorname{SiC}(\operatorname{Irr})$ & 31900. & 6.0 & 5.7 \\
\hline 17) & TM. 2 & $\operatorname{SiC}(\operatorname{Irr})$ & 31900 . & 6.0 & 5.7 \\
\hline 19) & TM. 3 & $\operatorname{SiC}(\operatorname{Irr})$ & 31900 . & 6.0 & 5.7 \\
\hline 21) & TM. 4 & $\operatorname{SiC}(\operatorname{Irr})$ & 31900 . & 6.0 & 5.7 \\
\hline 23) & Wire.1 & Moly & 42300 . & 0.7 & 0.7 \\
\hline 25) & Wire.2 & Moly & 42300 & 0.7 & 0.7 \\
\hline 27) & Spring.1 & $\operatorname{SiC}(\operatorname{Irr})$ & 31900 . & 3.0 & 2.9 \\
\hline 28) & Spring.2 & $\operatorname{SiC}(\operatorname{Irr})$ & 31900. & 3.0 & 2.9 \\
\hline 29) & Housing & $A L-6061$ & 31500 . & 135.0 & 128.9 \\
\hline 31) & Cap & $\mathrm{AL}-6061$ & 31500 . & 20.0 & 18.1 \\
\hline 33) & Thimble.1 & $\mathrm{Ti}-6 \mathrm{Al} 4 \mathrm{~V}$ & 34700 . & 5.2 & 5.1 \\
\hline 35) & Thimble.2 & $\mathrm{Ti}-6 \mathrm{Al} 4 \mathrm{~V}$ & 34700 . & 5.2 & 4.8 \\
\hline 37) & Container & $\mathrm{POCO}$ & 32300 . & 41.7 & 39.9 \\
\hline 39) & Specimen.1 & PyC & 32300 . & 0.2 & 0.2 \\
\hline 40$)$ & Specimen.2 & PyC & 32300 . & 0.2 & 0.2 \\
\hline 41) & Specimen. 3 & PyC & 32300 . & 0.2 & 0.2 \\
\hline 42$)$ & Specimen. 4 & $\mathrm{PyC}$ & 32300 . & 0.2 & 0.2 \\
\hline 43) & Specimen. 5 & $\mathrm{PyC}$ & 32300 . & 0.2 & 0.2 \\
\hline 44$)$ & Specimen. 6 & $\mathrm{PyC}$ & 32300 . & 0.2 & 0.2 \\
\hline 45) & Specimen. 7 & PyC & 32300 . & 0.2 & 0.2 \\
\hline 46) & Specimen. 8 & Pyc & 32300 . & 0.2 & 0.2 \\
\hline 47) & Specimen. 9 & PyC & 32300 . & 0.2 & 0.2 \\
\hline
\end{tabular}




\begin{tabular}{|c|c|c|c|c|c|}
\hline 48) & Specimen.10 & PyC & 32300 . & 0.2 & 0.2 \\
\hline 49) & Insulator.1 & GRAFOIL & 32300 . & 0.2 & 0.2 \\
\hline 51) & Insulator.2 & GRAFOIL & 32300 . & 0.2 & 0.2 \\
\hline 53) & Specimen.11 & PyC & 32300 . & 0.2 & 0.2 \\
\hline 54) & Specimen.12 & $\mathrm{PyC}$ & 32300 . & 0.2 & 0.2 \\
\hline 55) & Specimen.13 & PyC & 32300 . & 0.2 & 0.2 \\
\hline 56) & Specimen.14 & PyC & 32300 . & 0.2 & 0.2 \\
\hline 57) & Specimen.15 & $\mathrm{PyC}$ & 32300 . & 0.2 & 0.2 \\
\hline 58) & Specimen.16 & PyC & 32300 . & 0.2 & 0.2 \\
\hline 59) & Specimen.17 & PyC & 32300 . & 0.2 & 0.2 \\
\hline 60$)$ & Specimen.18 & $\mathrm{PyC}$ & 32300 . & 0.2 & 0.2 \\
\hline 61) & Specimen.19 & PyC & 32300 . & 0.2 & 0.2 \\
\hline 62) & Specimen.20 & $\mathrm{PyC}$ & 32300 . & 0.2 & 0.2 \\
\hline 63) & Specimen.21 & PyC & 32300 . & 0.2 & 0.2 \\
\hline 64) & Specimen.22 & PyC & 32300 . & 0.2 & 0.2 \\
\hline 65) & Specimen.23 & PyC & 32300 . & 0.2 & 0.2 \\
\hline 66) & Specimen.24 & PyC & 32300 . & 0.2 & 0.2 \\
\hline 67) & Specimen.25 & $\mathrm{PyC}$ & 32300 . & 0.2 & 0.2 \\
\hline 68) & Specimen.26 & PyC & 32300 . & 0.2 & 0.2 \\
\hline 69) & Specimen.27 & $\mathrm{PyC}$ & 32300 . & 0.2 & 0.2 \\
\hline 70) & Specimen.28 & $\mathrm{PyC}$ & 32300 . & 0.2 & 0.2 \\
\hline 71) & Specimen.29 & PyC & 32300 . & 0.2 & 0.2 \\
\hline 72) & Specimen.30 & $\mathrm{PyC}$ & 32300 . & 0.2 & 0.2 \\
\hline 73) & Specimen.31 & PyC & 32300 . & 0.2 & 0.2 \\
\hline 74) & Specimen. 32 & $\mathrm{PyC}$ & 32300 . & 0.2 & 0.2 \\
\hline 75) & Specimen.33 & $\mathrm{PyC}$ & 32300 . & 0.2 & 0.2 \\
\hline 76) & Specimen. 34 & $\mathrm{PyC}$ & 32300 . & 0.2 & 0.2 \\
\hline 77) & Specimen.35 & $\mathrm{PyC}$ & 32300 . & 0.2 & 0.2 \\
\hline 78) & Specimen.36 & $\mathrm{PyC}$ & 32300 . & 0.2 & 0.2 \\
\hline 79) & Specimen. 37 & PyC & 32300 . & 0.2 & 0.2 \\
\hline 80$)$ & Specimen.38 & $\mathrm{PyC}$ & 32300 . & 0.2 & 0.2 \\
\hline 81) & Specimen.39 & PyC & 32300 . & 0.2 & 0.2 \\
\hline 82) & Specimen. 40 & PyC & 32300 . & 0.2 & 0.2 \\
\hline & & & & 87.5 & 47.2 \\
\hline
\end{tabular}

CAPSULE TEMPERATURE SUMMARY

\begin{tabular}{|c|c|c|c|c|c|c|c|}
\hline \multicolumn{2}{|l|}{ Name } & Material & Tavg & $\operatorname{Tmin}$ & $\operatorname{Tmax}$ & T.025 & T. 975 \\
\hline 1) & Grafoil.1 & GRAFOIL & 93. & 86. & 100 & 87. & 97. \\
\hline 3) & Grafoil.2 & GRAFOIL & 114. & 96. & 158. & 98. & 131. \\
\hline 5) & Holder & $\mathrm{NB}-1 \mathrm{ZR}$ & 1077 . & 1009. & 1106. & 1025 . & 1102. \\
\hline 7) & Foil.1 & Moly & 1066. & 1055. & 1077. & 1058. & 1076. \\
\hline 9) & Foil.2 & Moly & 1043 . & 1042 . & 1044 . & 1042 . & 1044. \\
\hline 11) & Grafoil.3 & GRAFOIL & 1037. & 1035. & 1039. & 1035. & 1038. \\
\hline 13) & Grafoil.4 & GRAFOIL & 1037. & 1036. & 1039. & 1036. & 1038. \\
\hline 15) & TM. 1 & $\operatorname{SiC}(\operatorname{Irr})$ & 1096. & 1059. & 1113. & 1065. & 1112. \\
\hline 17) & TM. 2 & $\operatorname{SiC}(\operatorname{Irr})$ & 1085. & 1050 . & 1101. & 1055. & 1101. \\
\hline 19) & TM. 3 & $\operatorname{SiC}(\operatorname{Irr})$ & 1084 . & 1050 . & 1101. & 1054 . & 1100. \\
\hline 21) & TM. 4 & $\operatorname{SiC}(\operatorname{Irr})$ & 1097. & 1060 . & 1115. & 1066. & 1114. \\
\hline 23) & Wire.1 & Moly & 1070 . & 1064 . & 1073. & 1064 . & 1073. \\
\hline 25) & Wire.2 & Moly & 1060 . & 1056. & 1063. & 1056. & 1063. \\
\hline 27) & Spring.1 & $\operatorname{SiC}(\operatorname{Ir} r)$ & 1103. & 1054 . & 1129. & 1063. & 1128. \\
\hline 28) & Spring.2 & $\operatorname{SiC}(\operatorname{Irr})$ & 1107. & 1060 . & 1130. & 1065. & 1129. \\
\hline 29) & Housing & $A L-6061$ & 66 . & 57. & 73. & 58. & 71 . \\
\hline 31) & Cap & AL- 6061 & 148. & 146. & 150. & 146. & 150. \\
\hline 33) & Thimble.1 & Ti-6Al4V & 994. & 842 . & 1039. & 926. & 1032. \\
\hline 35) & Thimble.2 & Ti-6Al4V & 1003. & 855. & 1028 . & 947. & 1026. \\
\hline 37) & Container & $\mathrm{POCO}$ & 1113. & 1064. & 1133. & 1083. & 1132. \\
\hline 39) & Specimen.1 & PyC & 1109. & 1104. & 1115. & 1104. & 1114. \\
\hline 40) & Specimen.2 & PyC & 1120. & 1115. & 1125. & 1116. & 1124. \\
\hline 41) & Specimen.3 & PyC & 1128 & 1124. & 1131. & 1124. & 1130. \\
\hline 42) & Specimen. 4 & $\mathrm{PyC}$ & 1131. & 1129. & 1133. & 1129. & 1133. \\
\hline 43) & Specimen. 5 & PyC & 1132. & 1130. & 1133. & 1130. & 1133. \\
\hline 44) & Specimen. 6 & PyC & 1130. & 1128. & 1133. & 1128. & 1132. \\
\hline 45) & Specimen. 7 & $\mathrm{PyC}$ & 1127. & 1123. & 1130. & 1124. & 1129. \\
\hline 46) & Specimen. 8 & PyC & 1121. & 1117. & 1125. & 1117. & 1124. \\
\hline 47) & Specimen. 9 & $\mathrm{PyC}$ & 1113. & 1108. & 1118. & 1109. & 1117. \\
\hline 48) & Specimen.10 & PyC & 1104 . & 1099. & 1109. & 1099. & 1108. \\
\hline
\end{tabular}




\begin{tabular}{|c|c|c|c|c|c|c|c|}
\hline 49) & Insulator.1 & GRAFOIL & 1070 & 1060. & 1082 . & 1062 . & 1080. \\
\hline 51) & Insulator.2 & GRAFOIL & 1040 & 1036. & 1042 . & 1038. & 1041. \\
\hline 53) & Specimen.11 & PyC & 1111. & 1106. & 1116. & 1106. & 1116. \\
\hline 54) & Specimen.12 & Pyc & 1122 & 1117. & 1126. & 1118. & 1126. \\
\hline 55) & Specimen.13 & Pyc & 1129 & 1126. & 1132. & 1126. & 1132. \\
\hline 56) & Specimen.14 & PyC & 1133 & 1131. & 1135. & 1131. & 1134. \\
\hline 57) & Specimen.15 & PyC & 1134 & 1133. & 1135. & 1133. & 1135. \\
\hline 58) & Specimen.16 & PyC & 1133. & 1130. & 1134. & 1131. & 1134. \\
\hline 59) & Specimen.17 & PyC & 1129 & 1126. & 1131. & 1126. & 1131. \\
\hline 60$)$ & Specimen.18 & PyC & 1123 & 1119. & 1126. & 1119. & 1126. \\
\hline 61) & Specimen.19 & Pyc & 1115 & 1110 . & 1119. & 1111. & 1118. \\
\hline 62) & Specimen.20 & PyC & 1105 & 1101. & 1110. & 1101. & 1109. \\
\hline 63) & Specimen.21 & Pyc & 1109 & 1104. & 1115. & 1105. & 1114. \\
\hline 64) & Specimen.22 & PyC & 1120 & 1115. & 1124. & 1116. & 1124. \\
\hline 65) & Specimen.23 & PyC & 1128 & 1124. & 1130 . & 1125. & 1130. \\
\hline 66) & Specimen.24 & Pyc & 1132 & 1129. & 1133. & 1130. & 1133. \\
\hline 67) & Specimen.25 & PyC & 1132 & 1131. & 1133. & 1131. & 1133. \\
\hline 68) & Specimen.26 & Pyc & 1131. & 1129. & 1132. & 1129. & 1132. \\
\hline 69) & Specimen.27 & PyC & 1127 & 1124. & 1129. & 1124. & 1129. \\
\hline 70) & Specimen.28 & PyC & 1121 & 1117. & 1124. & 1118. & 1124 . \\
\hline 71) & Specimen.29 & PyC & 1113 & 1108. & 1117. & 1109. & 1116. \\
\hline 72) & Specimen.30 & PyC & 1103. & 1099. & 1108. & 1099. & 1107. \\
\hline 73) & Specimen.31 & PyC & 1102 & 1096. & 1108. & 1096. & 1107. \\
\hline 74) & Specimen.32 & PyC & 1113 & 1107. & 1118. & 1108. & 1117. \\
\hline 75) & Specimen.33 & PyC & 1120 & 1116. & 1124. & 1117. & 1123. \\
\hline 76) & Specimen.34 & Pyc & 1124 & 1122 . & 1126. & 1122 . & 1126. \\
\hline 77) & Specimen.35 & PyC & 1125 & 1123. & 1126. & 1124. & 1126. \\
\hline 78) & Specimen.36 & PyC & 1123 & 1121. & 1126. & 1121. & 1125. \\
\hline 79) & Specimen.37 & Pyc & 1120 & 1116. & 1123. & 1117. & 1122 . \\
\hline 80$)$ & Specimen.38 & PyC & 1113 & 1109. & 1118. & 1110. & 1117. \\
\hline 81) & Specimen.39 & PyC & 1105 & 1100 . & 1110. & 1100 . & 110 \\
\hline 82) & Specimen.40 & PyC & 1095 & 1089. & 1100 . & 1090. & 1099. \\
\hline
\end{tabular}

PROPERTY SUMMARY AT THE AVERAGE PART TEMPERATURE

\begin{tabular}{|c|c|c|c|c|c|}
\hline Name & & Material & $\begin{array}{l}\text { Thermal } \\
\text { Cond. } \\
\left(\mathrm{W} / \mathrm{m} \cdot{ }^{\circ} \mathrm{C}\right)\end{array}$ & $\begin{array}{l}\text { Thermal } \\
\text { Exp. } \\
\text { Coeff. } \\
\left(\mu \mathrm{m} / \mathrm{m} \cdot{ }^{\circ} \mathrm{C}\right)\end{array}$ & $\begin{array}{l}\text { Emis } \\
\quad(---)\end{array}$ \\
\hline 1) & Grafoil.1 & GRAFOIL & 38.000 & 1.00 & 0.500 \\
\hline 3) & Grafoil.2 & GRAFOIL & 38.000 & 1.00 & 0.500 \\
\hline 5) & Holder & NB-1ZR & 64.571 & 8.09 & 0.211 \\
\hline 7) & Foil.1 & Moly & 101.524 & 0.00 & 0.142 \\
\hline 9) & Foil.2 & Moly & 102.098 & 0.00 & 0.139 \\
\hline 11) & Grafoil.3 & GRAFOIL & 38.000 & 1.00 & 0.500 \\
\hline 13) & Grafoil.4 & GRAFOIL & 38.000 & 1.00 & 0.500 \\
\hline 15) & TM. 1 & $\operatorname{SiC}(\operatorname{Irr})$ & 40.813 & 4.41 & 0.900 \\
\hline 17) & TM. 2 & $\operatorname{SiC}(\operatorname{Irr})$ & 40.638 & 4.40 & 0.900 \\
\hline 19) & TM. 3 & $\operatorname{SiC}(\operatorname{Irr})$ & 40.625 & 4.40 & 0.900 \\
\hline 21) & TM. 4 & $\operatorname{SiC}(\operatorname{Irr})$ & 40.831 & 4.41 & 0.900 \\
\hline 23) & Wire.1 & Moly & 101.434 & 0.00 & 0.142 \\
\hline 25) & Wire. 2 & Moly & 101.673 & 0.00 & 0.141 \\
\hline 27) & Spring.1 & $\operatorname{SiC}(\operatorname{Ir} r)$ & 41.094 & 4.41 & 0.900 \\
\hline 28) & Spring.2 & $\operatorname{SiC}(\operatorname{Irr})$ & 41.355 & 4.42 & 0.900 \\
\hline 29) & Housing & $\mathrm{AL}-6061$ & 167.424 & 24.21 & 0.050 \\
\hline 31) & Cap & $\mathrm{AL}-6061$ & 175.671 & 0.00 & 0.050 \\
\hline 33) & Thimble.1 & $\mathrm{Ti}-6 \mathrm{Al} 4 \mathrm{~V}$ & 19.897 & 8.91 & 0.466 \\
\hline 35) & Thimble.2 & Ti-6Al4V & 19.905 & 8.94 & 0.466 \\
\hline 37) & Container & $\mathrm{POCO}$ & 29.600 & 8.40 & 0.800 \\
\hline 39) & Specimen.1 & PyC & 19.548 & 5.56 & 0.800 \\
\hline 40) & Specimen.2 & PyC & 19.657 & 5.57 & 0.800 \\
\hline 41) & Specimen. 3 & PyC & 19.730 & 5.57 & 0.800 \\
\hline 42) & Specimen. 4 & $\mathrm{PyC}$ & 19.766 & 5.57 & 0.800 \\
\hline 43) & Specimen. 5 & PyC & 19.773 & 5.58 & 0.800 \\
\hline 44) & Specimen. 6 & PyC & 19.758 & 5.57 & 0.800 \\
\hline 45) & Specimen. 7 & PyC & 19.722 & 5.57 & 0.800 \\
\hline 46) & Specimen. 8 & PyC & 19.666 & 5.57 & 0.800 \\
\hline 47) & Specimen.9 & PyC & 19.587 & 5.56 & 0.800 \\
\hline 48) & Specimen.10 & PyC & 19.491 & 5.55 & 0.800 \\
\hline
\end{tabular}




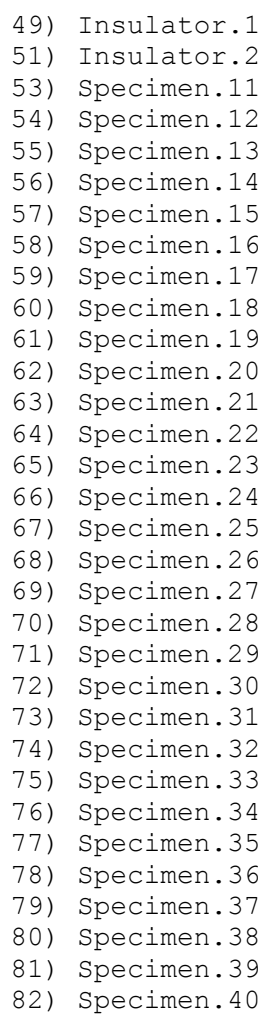

\begin{tabular}{|c|c|c|c|}
\hline GRAFOIL & 38.000 & 1.00 & 0.500 \\
\hline GRAFOIL & 38.000 & 1.00 & 0.500 \\
\hline PyC & 19.565 & 5.56 & 0.800 \\
\hline PyC & 19.674 & 5.57 & 0.800 \\
\hline PyC & 19.748 & 5.57 & 0.800 \\
\hline PyC & 19.785 & 5.58 & 0.800 \\
\hline PyC & 19.794 & 5.58 & 0.800 \\
\hline PyC & 19.778 & 5.58 & 0.800 \\
\hline PyC & 19.741 & 5.57 & 0.800 \\
\hline PyC & 19.683 & 5.57 & 0.800 \\
\hline PyC & 19.602 & 5.56 & 0.800 \\
\hline PyC & 19.508 & 5.55 & 0.800 \\
\hline PyC & 19.548 & 5.56 & 0.800 \\
\hline PyC & 19.656 & 5.57 & 0.800 \\
\hline PyC & 19.730 & 5.57 & 0.800 \\
\hline PyC & 19.768 & 5.57 & 0.800 \\
\hline PyC & 19.777 & 5.58 & 0.800 \\
\hline PyC & 19.761 & 5.57 & 0.800 \\
\hline PyC & 19.723 & 5.57 & 0.800 \\
\hline PyC & 19.664 & 5.57 & 0.800 \\
\hline PyC & 19.582 & 5.56 & 0.800 \\
\hline PyC & 19.486 & 5.55 & 0.800 \\
\hline PyC & 19.473 & 5.55 & 0.800 \\
\hline PyC & 19.584 & 5.56 & 0.800 \\
\hline PyC & 19.658 & 5.57 & 0.800 \\
\hline PyC & 19.695 & 5.57 & 0.800 \\
\hline PyC & 19.704 & 5.57 & 0.800 \\
\hline PyC & 19.688 & 5.57 & 0.800 \\
\hline PyC & 19.650 & 5.57 & 0.800 \\
\hline PyC & 19.590 & 5.56 & 0.800 \\
\hline PyC & 19.506 & 5.55 & 0.800 \\
\hline PyC & 19.409 & 5.55 & 0.800 \\
\hline
\end{tabular}

STORED ENERGY SUMMARY AT THE AVERAGE PART TEMPERATURE

Name

1) Grafoil.1

3) Grafoil.2

5) Holder

7) Foil.1

9) Foil.2

11) Grafoil.3

13) Grafoil.4

15) TM. 1

17) TM. 2

19) TM. 3

21) TM. 4

23) Wire.1

25) Wire.2

27) Spring.1

28) Spring.2

29) Housing

31) Cap

33) Thimble.1

35) Thimble.2

37) Container

39) Specimen.1

40) Specimen.2

41) Specimen.3

42) Specimen.4

43) Specimen.5

44) Specimen.6

45) Specimen.7

46) Specimen.8

47) Specimen.9

48) Specimen.10

49) Insulator.1

\begin{tabular}{|c|c|c|c|c|}
\hline Material & $\begin{array}{r}\text { Mass } \\
(g)\end{array}$ & $\begin{array}{l}\text { Tavg } \\
\left({ }^{\circ} \mathrm{C}\right)\end{array}$ & $\begin{array}{c}\text { Specific } \\
\text { Heat } \\
\left(\mathrm{J} / \mathrm{kg}^{\circ} \mathrm{C}\right)\end{array}$ & $\begin{array}{l}\text { Stored } \\
\text { Energy } \\
\quad(\mathrm{J})\end{array}$ \\
\hline-------- & ------ & ----- & ----- & \\
\hline RAFOIL & 0.007 & 93. & 700 & \\
\hline GRAFOIL & 0.007 & 114. & 700 . & . \\
\hline $\mathrm{NB}-1 \mathrm{ZR}$ & 14.485 & 1077 . & 351. & 5372 . \\
\hline oly & 0.035 & 1066 . & 313. & 12. \\
\hline oly & 0.035 & 1043 . & 311. & 11. \\
\hline GRAFOIL & 0.007 & 1037 . & 00. & 5. \\
\hline GRAFOIL & 0.007 & 1037 . & 700. & 5 . \\
\hline $\operatorname{SiC}(\operatorname{Irr})$ & 0.187 & 1096. & 1276 . & 257 . \\
\hline SiC (Irr) & 0.187 & 1085 . & 1274 . & 254 . \\
\hline $\operatorname{SiC}(\operatorname{Irr})$ & 0.187 & 1084 . & 1274 . & 253. \\
\hline SiC (Irr) & 0.187 & 1097 . & 1277 . & 257 . \\
\hline Moly & 0.017 & 1070 . & 314 . & 6. \\
\hline oly & 0.017 & 1060 . & 313. & 6. \\
\hline $\operatorname{SiC}(\operatorname{Irr})$ & 0.094 & 1103. & 1278 . & 130. \\
\hline $\operatorname{SiC}(\operatorname{Irr})$ & 0.094 & 1107 . & 1278 . & 131. \\
\hline$A L-6061$ & 4.285 & 66. & 890. & 177. \\
\hline AL- 6061 & 0.635 & 148 . & 949. & 77. \\
\hline $\mathrm{Ti}-6 \mathrm{Al} 4 \mathrm{~V}$ & 0.149 & 994. & 616. & 90. \\
\hline $\mathrm{Ti}-6 \mathrm{Al} 4 \mathrm{~V}$ & 0.149 & 1003 . & 493. & 72 . \\
\hline $\mathrm{POCO}$ & 1.290 & 1113. & 1963. & 2767 . \\
\hline PyC & 0.006 & 1109. & 1769 . & 11. \\
\hline PyC & 0.006 & 1120 . & 1774 . & 11. \\
\hline PyC & 0.006 & 1128 . & 1777 . & 12. \\
\hline PyC & 0.006 & 1131. & 1778 . & 12. \\
\hline PyC & 0.006 & 1132 . & 1779 . & 12 . \\
\hline PyC & 0.006 & 1130 . & 1778 . & 12. \\
\hline PyC & 0.006 & 1127 . & 1776 . & 12 . \\
\hline PyC & 0.006 & 1121. & 1774 . & 11. \\
\hline PyC & 0.006 & 1113. & 1770 . & 11. \\
\hline PyC & 0.006 & 1104 . & 1766 . & 11. \\
\hline GRAFOIL & 0.005 & 1070 . & 700 . & 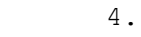 \\
\hline
\end{tabular}




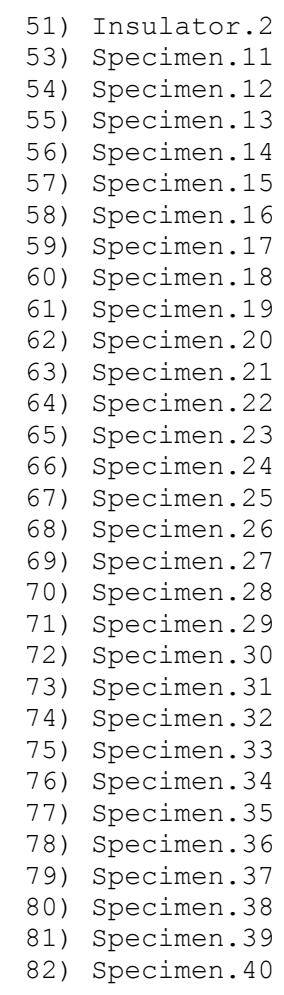

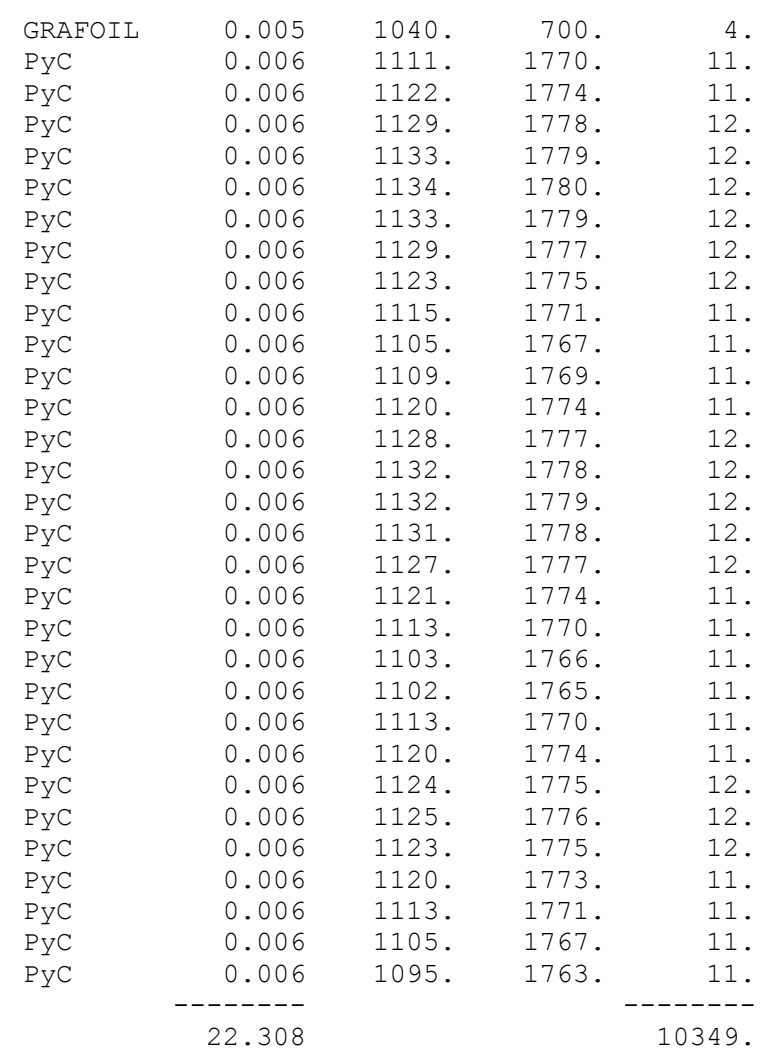

GAP REPORTS

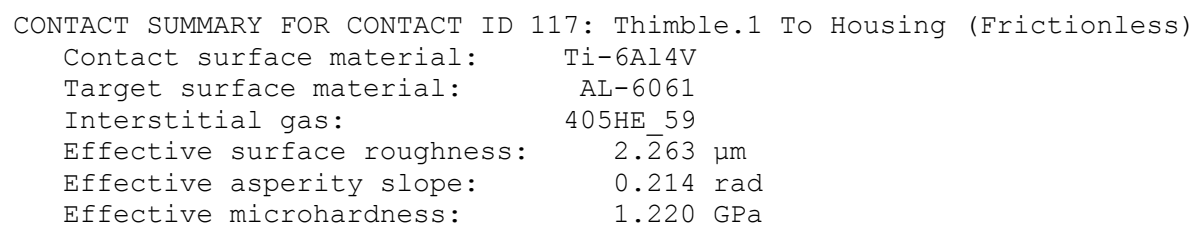




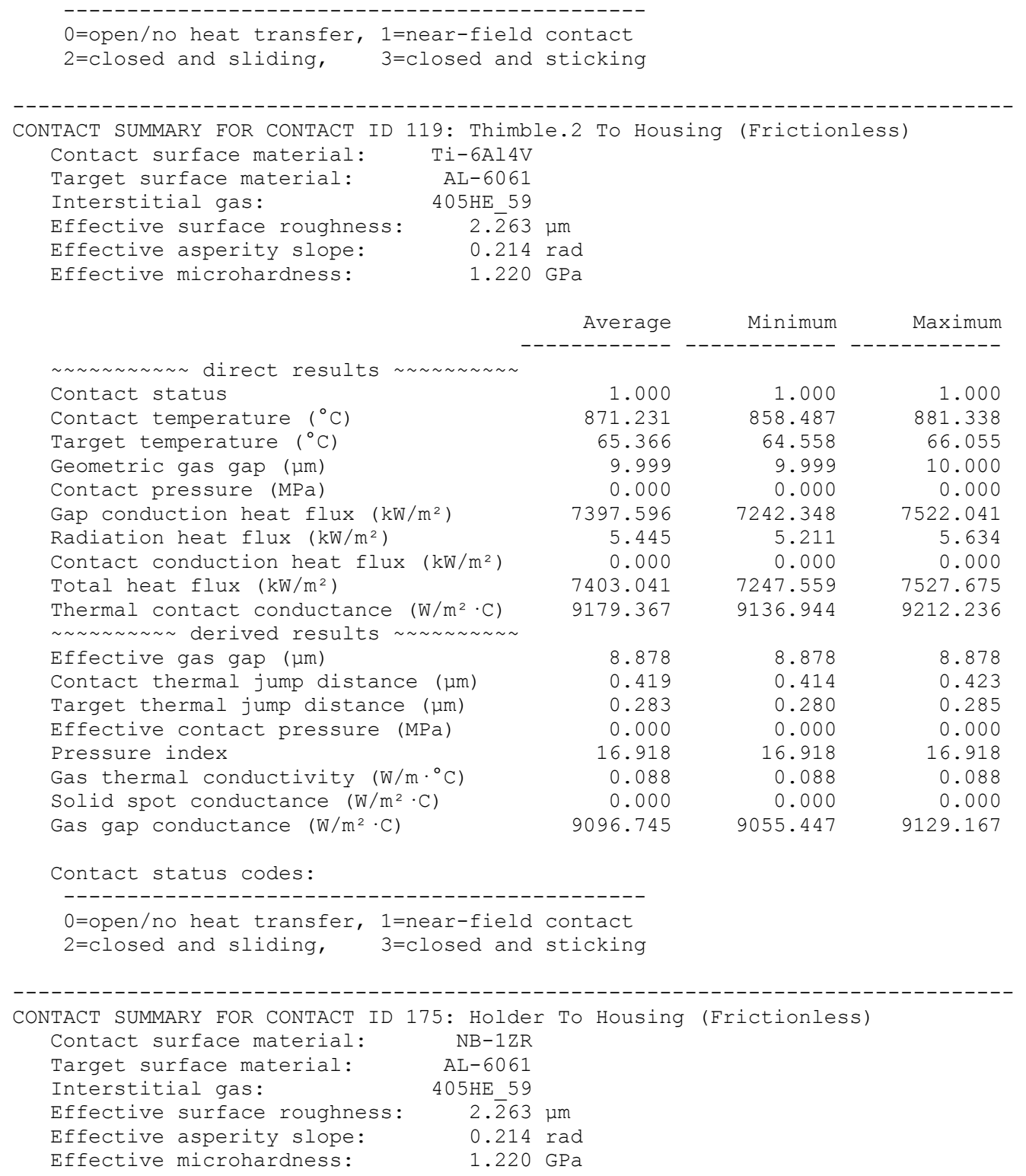

$\begin{array}{lrrr} & \text { Average } & \text { Minimum } & \text { Maximum } \\ & & & \\ \sim \sim \sim \sim \sim \sim & \\ \text { Contact status } & 1.000 & 1.000 & 1.000 \\ \text { Contact temperature }\left({ }^{\circ} \mathrm{C}\right) & 1071.570 & 1008.972 & 1098.282 \\ \text { Target temperature }\left({ }^{\circ} \mathrm{C}\right) & 67.823 & 62.185 & 68.605 \\ \text { Geometric gas gap }(\mu \mathrm{m}) & 254.999 & 254.556 & 255.362 \\ \text { Contact pressure }(\mathrm{MPa}) & 0.000 & 0.000 & 0.000 \\ \text { Gap conduction heat flux }\left(\mathrm{kW} / \mathrm{m}^{2}\right) & 433.189 & 393.323 & 451.043 \\ \text { Radiation heat flux }\left(\mathrm{kW} / \mathrm{m}^{2}\right) & 9.057 & 7.394 & 9.821 \\ \text { Contact conduction heat flux }\left(\mathrm{kW} / \mathrm{m}^{2}\right) & 0.000 & 0.000 & 0.000 \\ \text { Total heat flux }\left(\mathrm{kW} / \mathrm{m}^{2}\right) & 442.246 & 400.717 & 460.865 \\ \text { Thermal contact conductance }\left(\mathrm{W} / \mathrm{m}^{2} \cdot \mathrm{C}\right) & 431.453 & 416.205 & 438.572 \\ \sim \sim \sim \sim \sim \sim \sim & \\ \text { Effective gas gap }(\mu \mathrm{m}) & & & \\ \text { Contact thermal jump distance }(\mu \mathrm{m}) & 220.972 & 219.970 & 223.320 \\ \text { Target thermal jump distance }(\mu \mathrm{m}) & 0.708 & 0.664 & 0.726 \\ \text { Effective contact pressure }(\mathrm{MPa}) & 0.328 & 0.312 & 0.335 \\ \text { Pressure index } & 13.809 & 0.000 & 0.000 \\ \text { Gas thermal conductivity }\left(\mathrm{W} / \mathrm{m} \cdot{ }^{\circ} \mathrm{C}\right) & 0.096 & 13.809 & 13.809 \\ \text { Solid spot conductance }\left(\mathrm{W} / \mathrm{m}^{2} \cdot \mathrm{C}\right) & 0.000 & 0.093 & 0.097 \\ & & 0.000 & 0.000\end{array}$


Gas gap conductance $\left(W / m^{2} \cdot C\right)$

431.387

416.166

437.930

Contact status codes:

-------------------o---

$0=$ open/no heat transfer, 1 =near-field contact

2=closed and sliding, $\quad 3=$ closed and sticking 